\title{
Titer IgG Pertusis pada Usia Remaja, Dewasa, dan Orang Tua Mempergunakan Metode ELISA dan Mikroaglutinasi Pertusis
}

\author{
Novilia Sjafri Bachtiar, ${ }^{1}$ Sadeli Masria, ${ }^{2}$ Usep Abdullah Husin ${ }^{2}$ \\ ${ }^{1}$ Bagian Evaluasi Produk, PT. Bio Farma, Bandung \\ ${ }^{2}$ Departemen Mikrobiologi Fakultas Kedokteran Universitas Padjadjaran-Rumah Sakit Hasan Sadikin
}

\begin{abstract}
Abstrak
Imunisasi pertusis yang hanya diberikan pada masa bayi tidak dapat memberikan proteksi jangka panjang, sehingga terjadi reemerging pertusis. Tujuan penelitian ini adalah untuk mengetahui hubungan usia remaja, dewasa, dan orang tua dengan titer IgG pertusis menggunakan metode enzyme linked immunosorbent assay (ELISA) dan mikroaglutinasi pertusis (MAP). Penelitian observasi analitik dengan rancangan potong lintang ini dilakukan pada 402 subjek yang terdiri atas 134 remaja (12-18 tahun), 187 dewasa (19-49 tahun), dan 81 orang tua (50-64 tahun) di kota Bandung periode 2008-2010. IgG pertusis ditentukan dengan metode ELISA dan MAP. IgG pertusis positif berdasarkan ELISA ditemukan berturut-turut pada $92(68,7 \%)$ remaja, $143(76,5 \%)$ dewasa, dan $72(88,9 \%)$ orang tua $(\mathrm{p}=0,003)$. Menggunakan metode MAP persentase IgG pertusis positif pada usia remaja, dewasa, dan orang tua berturut-turut sebesar $27(20,1 \%), 9(4,8 \%)$, dan $3(3,37 \%)$, terjadi penurunan dengan bertambahnya usia $(\mathrm{p}<0,001)$, menunjukkan proteksi imunisasi tidak dapat bertahan lama. Bila sampel dengan MAP positif dikeluarkan untuk memperoleh titer IgG pertusis akibat infeksi pertusis alamiah maka diperoleh persentase IgG pertusis positif $68,9 \%$. Simpulan, terdapat hubungan antara usia dan titer IgG pertusis positif pada populasi remaja, dewasa, dan orang tua di kota Bandung menggunakan metode ELISA dan MAP. Persentase IgG positif hasil pengukuran ELISA meningkat dengan semakin bertambahnya usia. [MKB. 2011;43(1):10-5].
\end{abstract}

Kata kunci: Bordetella pertussis, enzyme linked immunosorbent assay, IgG, mikroaglutinasi

\section{Pertussis IgG Titer Percentage in Adolescents, Adults, and Elderly Using ELISA Method and Pertussis Microagglutination}

\begin{abstract}
Pertussis antigen which only given in primary immunization, could not protect for a long period. In some countries whooping cough became an reemerging disease. The objective of this study was to evaluate the correlation between age and percentage of positive IgG pertussis in adolescent, adult, and elderly population using enzyme link immunosorbent assay (ELISA) and microagglutination. This observational analytic with cross sectional study was done on 402 subjects, consisted of 134 adolescents (12-18 years), 187 adults (19-49 years), and 81 elderly (50-64 years) in Bandung, period 2008-2010. Titer of pertussis IgG was measured using ELISA and microagglutination of pertussis (MAP). The ELISA results showed positive IgG pertussis in $92(68.7 \%)$ adolescent, $143(76.5 \%)$ adults, and $72(88.9 \%)$ elderly $(\mathrm{p}=0.003)$. The results of MAP showed positive pertussis IgG in adolescent, adults, and elderly were $27(20.1 \%), 9(4.8 \%)$, and $3(3.37 \%)$, respectively, which was decreased with age $(p<0.001)$. If MAP positive samples were excluded from the analysis in ELISA positive samples, which express the IgG pertussis due to contact with circulate $\mathrm{B}$, the pertussis IgG positive was $68.9 \%$. In conclusion, there is a correlation between age and percentage of positive IgG pertussis titer in adolescent, adult, and ederly population in Bandung using ELISA and MAP methods. Positive pertussis IgG by ELISA is increased with age. [MKB. 2011;43(1):10-5].
\end{abstract}

Key words: Bordetella pertussis, enzyme linked immunosorbent assay, IgG, microagglutination

Korespondensi: Novilia Sjafri Bachtiar, Bagian Evaluasi Produk, PT. Bio Farma, Bandung, jalan Pasteur 28 Bandung, mobile08122307741,e-mail novilia@biofarma.co.id 


\section{Pendahuluan}

Penyakit pertusis atau dikenal dengan batuk rejan atau batuk 100 hari, merupakan penyakit infeksi saluran pernapasan yang disebabkan oleh bakteri kokobasilus Gram negatif Bordetella pertussis. ${ }^{1,2}$ Pertusis pada anak biasanya diawali dengan stadium kataral (catarrhal) berupa gejala ringan pada infeksi saluran pernapasan bagian atas, seperti flu pada umumnya. Stadium paroksismal dengan batuk terus-menerus disertai inspirasi panjang dan suara batuk yang khas (whoop), biasanya diikuti dengan muntah. Gejala biasanya menetap selama berminggu-minggu hingga berbulan-bulan (stadium konvalesens). ${ }^{3}$

Pertusis pada anak yang lebih besar dan dewasa biasanya atipikal atau tidak menunjukkan gejala spesifik dan tidak disertai dengan pernapasan paroksismal. ${ }^{2}$ Remaja dan dewasa tidak berobat karena gejala pertusis yang tidak khas, sedangkan mereka mempunyai potensi menularkan pada kelompok rentan. Dengan demikian, remaja dan dewasa sering menjadi sumber penularan bagi bayi. $^{4,5}$

Di Indonesia vaksin DPT yang mengandung antigen pertusis mulai diperkenalkan pada tahun 1976 dan tahun 1977. World Health Organization (WHO) telah menetapkan program pengembangan Expanded Program on Immunization (EPI) sebagai upaya global. ${ }^{6}$ Imunisasi yang mengandung antigen pertusis hanya diberikan pada bayi berupa vaksin DTP atau DTP/HB (difteria, tetanus, pertusis, dan hepatitis B). Vaksin ini diberikan mulai usia dua bulan sebanyak tiga dosis dengan interval satu bulan. ${ }^{6}$

Seiring dengan berjalannya waktu, ancaman terjadinya pertusis timbul akibat menurunnya kekebalan setelah imunisasi. Observasi epidemiologi menunjukkan bahwa proteksi yang ditimbulkan imunisasi hanya untuk waktu yang terbatas dan menurun secara bertahap. Hanya $46 \%$ anak yang masih protektif terhadap pertusis setelah tahun ketujuh. Pada penelitian lain hanya $76 \%$ bayi masih protektif terhadap pertusis pada akhir tahun kedua setelah imunisasi dasar. ${ }^{7}$ Literatur lain menyatakan bahwa kekebalan ratarata setelah imunisasi DTP (whole cell) akan turun lebih dari 50\% dalam 6-12 tahun. ${ }^{5}$

Pertusis akhir-akhir ini dikenal sebagai salah satu penyakit yang tergolong sebagai reemerging disease. ${ }^{8}$ Fenomena ini terjadi di negara maju seperti Canada, Australia, dan Amerika Serikat. ${ }^{9-13}$ Beberapa negara berkembang seperti Singapura, Slovenia, dan Cekoslowakia juga menemukan fenomena serupa. ${ }^{14-17}$ Secara global diperkirakan sebanyak 17,6 juta kasus pertusis timbul di dunia, 90\% di antaranya terjadi di negara berkembang dan 279.000 pasien meninggal pada tahun 2003. ${ }^{18}$
Di Indonesia belum ada informasi mengenai titer antibodi atau imunoglobulin $\mathrm{G}$ (IgG) pertusis pada populasi remaja, dewasa, dan orang tua. Informasi ini sangat diperlukan untuk mengetahui apakah terdapat sirkulasi pertusis secara alami pada kelompok usia tersebut. Sampai saat ini belum ada vaksin Tdap di Indonesia, sedangkan vaksin DTP hanya diberikan pada anak usia $<5$ tahun. Dengan demikian antibodi yang ditemukan pada kelompok usia ini kemungkinan besar bukan berasal dari imunisasi, tetapi dari infeksi pertusis.

Tingginya kasus pada bayi berusia $<6$ bulan akhir-akhir ini di berbagai negara, mendorong dilakukannya penelitian antara lain di Amerika Serikat, untuk mengetahui sumber penularan pertusis pada bayi $<6$ bulan. Kekebalan terhadap pertusis karena imunisasi belum terbentuk sempurna. Anggota keluarga serumah berperan terjadinya transmisi pertusis pada bayi sebesar $76 \%$ sampai 83\%. ${ }^{16}$ Endemik pada remaja dan orang dewasa mempunyai peranan terhadap siklus penyakit pada anak yang tidak atau belum lengkap diimunisasi. ${ }^{1,16}$

Tujuan penelitian ini untuk mengetahui hubungan usia remaja, dewasa, dan orang tua dengan titer IgG pertusis menggunakan metode enzyme link immunosorbent assay (ELISA) dan mikroaglutinasi pertusis (MAP). Metode ELISA dapat mengukur IgG, baik karena imunisasi maupun infeksi alamiah, sedangkan metode MAP terutama digunakan untuk evaluasi titer aglutinin setelah imunisasi DTP (whole cell).

\section{Metode}

Penelitian observasi analitik dengan rancangan potong lintang dilakukan pada 402 subjek yang terdiri atas 134 remaja (12-18 tahun), 187 dewasa (19-49 tahun), dan 81 orang tua (50-64 tahun) di kota Bandung periode tahun 2008-2010.

Penelitian ini dilakukan di Laboratorium Evaluasi Produk PT. Bio Farma Bandung, bulan April tahun 2010 dengan sampel berupa serum. Persetujuan Etik telah diperoleh dari Komite Etik Penelitian Kesehatan Fakultas Kedokteran Unpad-RSUP Dr. Hasan Sadikin Bandung.

Besar sampel ditentukan menggunakan estimasi proporsi dari Snedecor dan Cochran berdasarkan pada perkiraan persentase seroprevalensi pertusis. Berdasarkan data seroprevalensi sebesar 50-97\% di berbagai negara, ${ }^{18}$ maka jumlah sampel minimal yang diperlukan adalah 385 . Pada penelitian ini serum yang telah tersedia adalah 402 .

Titer IgG ditentukan menggunakan metode ELISA dan dinyatakan positif bila hasilnya $>24$ $\mathrm{U} / \mathrm{mL}$. Titer yang diperoleh merupakan endpoint titrasi serum. Titer IgG memakai metode MAP 
dinyatakan positif bila $>1: 80$ atau $>80(1 /$ dil $)$. Serum akan terus dititrasi hingga diperoleh nilai endpoint.

Prevalensi titer IgG positif akan dianalisis menurut kelompok usia menggunakan metode chi-kuadrat dengan kemaknaan $5 \%(\mathrm{p} \leq 0,05)$.

Perbedaan persentase IgG pertusis positif berdasarkan ELISA dan MAP dapat menentukan apatah harus dilakukan pemeriksaan dengan dua metode uji atau cukup metode ELISA.

Analisis data mempergunakan chi-square test dengan program SPSS for windows versi 13.0 pada derajat kepercayaan $95 \%$ dengan nilai $\mathrm{p} \leq 0,05$.

\section{Hasil}

Usia rerata subjek penelitian ini adalah 32 tahun, median 29 tahun, paling banyak subjek adalah usia 19-49 tahun sebanyak 187 orang (46,5\%).

Persentase IgG pertusis positif berdasarkan metode ELISA dan MAP dapat dilihat pada Tabel 1. Terlihat bahwa persentase IgG pertusis positif menggunakan metode ELISA cukup tinggi, yaitu 307 orang $(76,4 \%)$, sedangkan hasil negatif sebesar 95 orang (23,6\%); dengan menggunakan metode MAP, persentase IgG pertusis positif jauh lebih sedikit, yaitu 39 orang $(9,7 \%)$, sebaliknya persentase $\operatorname{IgG}$ pertusis negatif sangat tinggi, yaitu 363 orang $(90,3 \%)$.

Hubungan kelompok usia dengan persentase IgG pertusis positif berdasarkan metode ELISA dan MAP dapat dilihat pada Tabel 2.

Persentase IgG pertusis positif dengan
Tabel 1 Persentase IgG Pertusis berdasarkan Metode ELISA dan MAP

\begin{tabular}{ccc}
\hline \multirow{2}{*}{ IgG } & ELISA & MAP \\
\cline { 2 - 3 } & $\mathbf{n ~ ( \% )}$ & $\mathbf{n ~ ( \% )}$ \\
\hline Positif & $307(76,4)$ & $39(9,7)$ \\
Negatif & $95(23,6)$ & $363(90,3)$ \\
\hline
\end{tabular}

menggunakan metode ELISA lebih banyak pada kelompok usia 50-64 tahun $(88,9 \%)$ dan paling sedikit pada usia 12-18 (68,7\%). Persentase IgG pertusis positif rata-rata adalah 33,4 tahun, sedangkan IgG pertusis negatif usia rata-rata lebih muda, yaitu 27,5 tahun. Hasil analisis chi-square test pada derajat kepercayaan $95 \%$ menunjukkan hubungan bermakna antara kelompok usia dan IgG pertusis positif berdasarkan metode ELISA $(\mathrm{p}=0,003)$. Persentase $\mathrm{IgG}$ pertusis positif berdasarkan metode MAP lebih banyak pada usia $12-18$ tahun atau remaja $(20,1 \%)$ dan paling sedikit pada usia 50-64 tahun atau kelompok orang tua sebesar $3,7 \%$. Persentase IgG pertusis positif dengan metode MAP terdapat pada usia rerata lebih muda (21,56 tahun), sedangkan IgG pertusis negatif terdapat pada usia rerata lebih tinggi, yaitu 33,2 tahun. Hasil analisis chi-square test pada derajat kepercayaan $95 \%$ menunjukkan hubungan bermakna antara kelompok usia dan IgG pertusis positif menggunakan metode MAP $(\mathrm{p}<0,001)$.

Metode ELISA menentukan titer IgG pertusis setelah imunisasi dan infeksi alami, sedangkan metode MAP hanya mengukur titer aglutinin (IgG) setelah imunisasi. Apabila

Tabel 2 Persentase IgG Pertusis berdasarkan Metode ELISA dan MAP Sesuai Kelompok Usia

\begin{tabular}{|c|c|c|c|c|c|}
\hline \multirow{3}{*}{ Kelompok Usia (tahun) } & \multicolumn{4}{|c|}{ IgG } & \multirow{3}{*}{ Nilai $p$} \\
\hline & \multirow{2}{*}{\multicolumn{2}{|c|}{$\begin{array}{c}\text { Positif } \\
n=402(\%) \\
\end{array}$}} & \multirow{2}{*}{\multicolumn{2}{|c|}{$\begin{array}{c}\text { Negatif } \\
\mathrm{N}=402(\%) \\
\end{array}$}} & \\
\hline & & & & & \\
\hline \multicolumn{6}{|l|}{ ELISA } \\
\hline $12-18$ & 92 & $(68,7 \%)$ & 42 & $(31,3 \%)$ & $\left.0,003^{*}\right)$ \\
\hline $19-49$ & 143 & $(76,5 \%)$ & 44 & $(23,5 \%)$ & \\
\hline $50-64$ & 72 & $(88,9 \%)$ & 9 & $(11,1 \%)$ & \\
\hline Usia rerata $(\mathrm{SB})$ & 33,4 & $(16,06)$ & 27 & $2(14,26 \%)$ & \\
\hline \multicolumn{6}{|l|}{ MAP } \\
\hline $12-18$ & 27 & $(20,1 \%)$ & 107 & $(79,9 \%)$ & $<0,001^{*}$ \\
\hline $19-49$ & 9 & $(4,8 \%)$ & 178 & $(95,2 \%)$ & \\
\hline $50-64$ & 3 & $(3,7 \%)$ & 78 & $(96,3 \%)$ & \\
\hline Usia rerata $(\mathrm{SB})$ & 21,5 & $5(13,02)$ & 33 , & $6(15,72 \%)$ & \\
\hline
\end{tabular}


Tabel 3 Persentase IgG Positif Menurut Kelompok Usia

\begin{tabular}{|c|c|c|}
\hline Kelompok Usia & IgG Positif & Nilai p \\
\hline $12-18$ tahun $\quad(n=134)$ & $(53,7 \%)$ & \multirow{4}{*}{$\left.<0,001^{*}\right)$} \\
\hline $19-49$ tahun $\quad(n=187)$ & $135 \quad(72,2 \%)$ & \\
\hline 50-64 tahun $\quad(\mathrm{n}=81)$ & $(85,2 \%)$ & \\
\hline Rerata (SB) & $34,66(15,836)$ & \\
\hline
\end{tabular}

subjek MAP positif dikeluarkan pada subjek yang memberikan gambaran positif pada metode ELISA, diharapkan akan diperoleh subjek dengan titer IgG akibat infeksi alamiah, yaitu 276 orang $(68,9 \%)$. Gambaran subjek dengan titer IgG alamiah menurut kelompok usia dapat dilihat pada Tabel 3.

Tabel 3 menunjukkan persentase IgG positif terhadap pertusis menggunakan metode ELISA pada titer alamiah lebih banyak pada kelompok usia 50-64 tahun. Hal ini berarti pada usia tua sebesar $85,2 \%$ dan paling sedikit pada kelompok usia 12-18 atau remaja, yaitu 53,7\%. Persentase IgG positif terhadap pertusis akibat infeksi alamiah menggunakan metode ELISA dengan usia rerata lebih tua, yaitu 34,66 tahun, sedangkan pada IgG negatif dengan usia rerata 27,52 tahun. Hasil analisis chi-square test pada derajat kepercayaan $95 \%$ menunjukkan hubungan bermakna antara kelompok usia dan persentase IgG positif terhadap pertusis akibat infeksi alamiah berdasarkan metode ELISA dengan nilai $\mathrm{p}<0,001(\mathrm{p} \leq 0,05)$.

\section{Pembahasan}

Persentase IgG positif menurut metode ELISA sangat tinggi $(76,4 \%)$, sedangkan menurut MAP sangat rendah, yaitu hanya $9,7 \%$. Hal ini menunjukkan bahwa pada kelompok usia 1264 tahun titer $\operatorname{IgG}$ pertusis akibat imunisasi sangat rendah dan titer yang tinggi pada ELISA kemungkinan adalah dari infeksi alamiah.

Pada Tabel 2 terlihat bahwa persentase IgG positif terhadap pertusis menurut metode ELISA lebih banyak pada kelompok usia 50-64 tahun berarti pada populasi orang tua, yaitu sebesar $88,9 \%$ dan paling sedikit pada kelompok usia 12 18 atau populasi remaja, yaitu $68,7 \%$. Hubungan yang bermakna menurut usia ini dapat dijelaskan karena kelompok usia tua (50-64 tahun) selain efek imunisasi yang sudah tidak ada atau sangat kecil, merupakan kelompok usia yang paparan terhadap kemungkinan infeksi alamiah paling lama, sehingga semakin tua usia, maka semakin besar kemungkinan sudah terpapar dengan pertusis alamiah dari lingkungan. Fenomena yang sama sesuai dengan literatur, yaitu studi serologi menunjukkan bahwa proporsi orang dengan $\operatorname{IgG}$ terhadap toksin pertusis meningkat dengan meningkatnya usia yang merefleksikan kontak terhadap B. pertussis. ${ }^{16}$

Berdasarkan Tabel 2 juga terlihat bahwa persentase IgG positif terhadap pertusis menurut metode MAP lebih banyak pada kelompok usia 12-18 tahun, berarti populasi remaja sebesar $20,1 \%$ dan paling sedikit pada kelompok usia 50-64 atau populasi orang tua, yaitu 3,7\%. Hubungan bermakna antara kelompok usia dan persentase $\mathrm{IgG}$ pertusis positif menggunakan metode MAP adalah semakin kecilnya persentase dengan bertambahnya usia. Hal ini dapat dijelaskan karena MAP menunjukkan titer aglutinin (IgG) akibat imunisasi, sedangkan di Indonesia, imunisasi yang mengandung antigen pertusis hanya pada masa bayi, yaitu pemberian 3 dosis DTP atau DTP/HB mulai pada usia 2 bulan dengan interval 1 bulan. Semakin bertambahnya usia akan semakin rendah titernya dan semakin sedikit persentase positif terhadap IgG pertusis. Lamanya titer proteksi sangat bergantung pada jumlah dosis yang diterima dan interval antara masing-masing dosis.

Pada literatur dikatakan bahwa titer akan turun menjadi $49 \%$ protektif setelah tahun ketujuh. ${ }^{16}$ Pada studi ini titer aglutinin positif hanya tinggal 9,7\% setelah lebih dari 11 tahun dari imunisasi dasar, dengan persentase terbesar pada kelompok usia remaja (20,1\%). Hal ini menunjukkan bahwa imunisasi ketika bayi saja tidak cukup untuk memberikan proteksi hingga usia remaja.

Pada penelitian ini diperoleh titer persentase IgG alamiah pada populasi remaja, dewasa, dan orang tua (12-64 tahun) adalah $68,9 \%$. Hal ini berarti bahwa populasi remaja, dewasa, dan orang tua di kota Bandung telah terpapar pertusis cukup besar. Perlu diperhitungkan kemungkinan reemerging pertusis juga terjadi di Indonesia.

Pada literatur dikatakan angka seropositif ini bervariasi di setiap negara. Di Kamerun angka seropositif untuk pertusis sudah melebihi $80 \%$ pada anak usia 10 tahun, sedangkan di Selandia Baru, pada usia 15 tahun seropositif 
hanya mencapai 40\%. Di Italia karena cakupan imunisasi DTP yang rendah, seropositif akibat infeksi pertusis dengan metode ELISA adalah $56 \%$ dengan peningkatan dari $24 \%$ pada usia $1-3$ tahun menjadi $67 \%$ pada usia 11 hingga 12 tahun.

Fenomena reemerging pertusis juga terjadi di Iran, terbukti setelah dilakukan studi pada tahun 2007 menggunakan metode ELISA dengan cut-off $>24 \mathrm{U} / \mathrm{mL}$ ditemukan seropositif sebesar $47,6 \%$ pada usia 16-24 tahun. ${ }^{19}$ Bila dilihat pada penelitian kami, kelompok usia remaja menunjukkan angka yang lebih besar, yaitu $53,7 \%$. Studi lain di Pakistan menemukan serologi positif terhadap pertusis pada subjek usia 18-45 tahun adalah $89 \%$. Tingginya angka seropositif di Pakistan juga diduga akibat infeksi alamiah, direkomendasikan imunisasi yang mengandung antigen pertusis (Tdap) pada orang dewasa. ${ }^{20}$

Di daerah endemis, remaja dan orang dewasa bertanggung jawab pada siklus penyakit yang terjadi pada anak yang tidak atau belum lengkap diimunisasi. ${ }^{4,11,16}$ Perlu diwaspadai di Indonesia bagaimana dengan beban penyakit pertusis pada bayi dan anak. Bila ternyata beban penyakitnya cukup tinggi maka perlu dipikirkan kemungkinan melakukan intervensi dengan pemberian vaksin Tdap pada kelompok usia di atas 7 tahun.

Penelitian ini menunjukkan bahwa terdapat hubungan yang bermakna antara usia dan persentase positif terhadap IgG pertusis, baik menggunakan metode ELISA maupun MAP. Persentase IgG pertusis yang positif akibat infeksi alamiah cukup besar $(68,9 \%)$. Perlu diwaspadai kemungkinan reemerging pertusis di Indonesia dan kemungkinan kelompok usia 12-64 tahun menjadi sumber penularan bagi bayi dan anak yang tidak atau belum diimunisasi.

\section{Ucapan Terima Kasih}

Ucapan terima kasih penulis tujukan kepada PT. Bio Farma yang telah mensponsori penelitian ini.

\section{Daftar Pustaka}

1. Brooks GF, Carroll KC, Butel JS, Morse, Jawets SS. Melnick \& Adelberg's medical microbiology. Edisi ke-24. New York: Mc Graw Hill; 2007.

2. Tortora GJ, Funke BR, Case CL. Microbiology an introduction. Edisi ke-10. USA: Pearson; 2010.

3. American Academy of Pediatrics. Pertussis (whooping cough). Section 3. Summaries of infections diseases. Red Book. 2009. (diunduh 28 Desember 2009). Tersedia dari: http://aapredbook.aappublications.org/cgi/ content/full/2006/1/3.96.

4. Broder KR, Cortese MMC, Iskander JK, Kretsinger K, Slade BA, Brown KH. Preventing tetanus, diphtheria and pertussis among adolescents: use of tetanus toxoid, reduced diphtheria toxoid and acellular pertussis vaccines; recommendation of the Advissory Committee on Immunization Practices (ACIP). MMW Report. 2006;55 (RR-3):1-7.

5. Edwards, KM, Decker MD. Pertussis vaccine; vaccine (Plotkin). Edisi ke-5. USA: SaundersElsevier; 2009.

6. Departemen Kesehatan Republik Indonesia. Pedoman penyelenggara imunisasi. Jakarta: DepKes RI; 2005.

7. Galazka AM. WHO; Pertussis; Module 4; Global programme for vaccines and immunization expanded programme on immunization. WHO/EPI/GEN/93.14. Geneva: WHO; 1993.

8. Cockerill III FR, Smith TF. Response of the clinical microbiology laboratory to emerging (new) and reemerging infectious diseases. J Microbiol. 2004;42(6):2359-65.

9. Nardone A, Pebody RG, Maple PAC, Andrews N, Gay NJ, Miller E. Sero-epidemiology of Bordetella pertussis in England \& Wales. Vaccine. 2004;22:1314-9.

10. Galanis E, King AS, Varughese P, Halperin SA. Changing epidemiology and emerging risk groups for pertussis. Canadian Med Assoc J. 2006;174(4):451-2.

11. Forsyth K. Pertussis, still a formidable foe. Clin Infect Dis. 2007;45(11):1487-90.

12. Mooi FR, de Greeff SC. The case for maternal vaccination against pertussis. Lancet Infect Dis. 2007;7(9):614-24.

13. Kriz B, Fabiánová K, Maixnerová M, Benes C, Malý M. Pertussis: a reemerging infection? Epidemiol Microbiol Immunol. 2007;56(2):51-6.

14. SmithAW, Ng S, EarnestA. Seroepidemiology of pertussis in the adult population of Singapore. Ann Acad Med Singapore. 2006; 35:780-2.

15. Vitek MG, Klavs I, Kraigher A. Reemergence of pertussis in Slovenia: time to change immunization policy. Vaccine. 2008; 26(15):1874-8.

16. Wendelboe AM, Njamkepo E, Bourillon A, Florest DD, Geudelus J, Gerber M. Infant pertussis study group. Transmission of Bordetella pertussis to young infants. Pediat Infect Dis J. 2007;26(4):293-9.

17. AksakalFN, Cőplü N, Ceyhan MN, SőnmezC, Azkan S, Esen B. High incidence of pertussis among school children with prolonged cough in Turkey. Tohoku J Exp Med. 2007;211:353- 
68.

18. World Health Organization. Pertussis vaccine, position paper. Weekly Epidemiological Record. 2005;80(4):31-8.

19. HashemiSH, RanjbarM,HajilooiM,Seif-Tabiei MA, Bolandi M, Moghimi J. Seroprevalence of Immunoglobulin $\mathrm{G}$ antibodies against pertussis toxin among asymptomatic medical students in the west of Iran: a cross sectional study. BMC Infect Dis J. 2009;9:(58):1-4.

20. Syed MA, Said F, Bukhari HA. Seroepidemiology of Bordetella pertussis infections in the twin cities of Pakistan. North Am J Med Sci. 2009;1(7):353-5. 